\title{
EFFECT OF THERMAL PROCESSING ON CHEMICAL COMPOSITIONS, BIOACTIVE COMPOUNDS, AND ANTIOXIDANT ACTIVITIES OF COWPEA CULTIVARS ${ }^{1}$
}

\author{
RODRIGO BARBOSA MONTEIRO CAVALCANTE ${ }^{2}$, MARCOS ANTÔNIO DA MOTA ARAÚJO ${ }^{3}$, \\ MAURISRAEL DE MOURA ROCHA ${ }^{4}$, REGILDA SARAIVA DOS REIS MOREIRA-ARAÚJO ${ }^{5 *}$
}

\begin{abstract}
This study aimed to determine the effect of cooking on the centesimal compositions, the content of bioactive compounds, and antioxidant activities in beans of the cowpea cultivars. The beans were cooked without soaking $(1: 5 \mathrm{w} / \mathrm{v})$ in a pressure cooker for 780 seconds. Statistical analysis was performed using Student's t-test to determine the difference between means of raw and cooked beans. One-way ANOVA: post-hoc Tukey's test was applied at 5\% to compare the data of the cultivars. Significant difference (p 0.05) was noted between the moisture contents of samples, with values ranging from 10.69 to $11.37 \%$ in the raw beans and 63.32 to $75.43 \%$ in the cooked ones. Only BRS Marataoã showed a slight reduction $(1.24 \%)$ in the energy value. The total polyphenol content in cooked beans decreased on discarding the broth. BRS Marataoã showed the highest levels of total polyphenols and flavonoids in raw beans, cooked beans, and broth. The raw beans of the cultivar BRS Itaim had greater content of condensed tannins and total anthocyanins. The raw beans, cooked beans, and broth showed statistically significant differences between their antioxidant activities, and the best results were found in the samples not subjected to thermal processing, particularly in BRS Marataoã. In conclusion, cooking influenced the concentration of bioactive compounds and antioxidant activities of the beans. Therefore, it is recommended that cooked cowpea beans should be consumed with the cooking broth for optimization of antioxidants.
\end{abstract}

Keywords: Functional foods. Antioxidants. Cooking. Vigna unguiculata (L.) Walp.

\section{EFEITO DO PROCESSAMENTO TÉRMICO NA COMPOSIÇÃO QUÍMICA, COMPOSTOS BIOATIVOS E ATIVIDADE ANTIOXIDANTE DE CULTIVARES DE FEIJÃO-CAUPI}

\begin{abstract}
RESUMO - Este trabalho objetivou verificar o efeito da cocção na composição centesimal, no conteúdo de compostos bioativos e na atividade antioxidante em grãos de cultivares de feijão-caupi. Estes foram cozidos sem maceração (1:5 p/v) em panela de pressão por 780 segundos. Na análise estatística utilizou-se o teste $t$ de Student para verificar diferença entre a média dos grãos crus e cozidos. Por meio do método de one-way ANOVA: post-hoc, aplicou-se o teste de médias de Tukey ao nível de 5\% para as demais variáveis. Em relação à composição centesimal, houve diferença significativa $(\mathrm{p}<0,05)$ apenas para o teor de umidade, com valores de 10,69 a $11,37 \%$ nos grãos crus e 63,32 a $75,43 \%$ nos cozidos. Apenas a cultivar BRS Marataoã apresentou discreta redução $(1,24 \%)$ no valor energético. Quanto aos polifenóis totais, observou-se uma diminuição do conteúdo nos grãos cozidos, com retenção no caldo. A cultivar BRS Marataoã destacou-se com os maiores teores de polifenóis totais e flavonóides totais nos grãos crus, cozidos e caldo. Observou-se, nos grãos crus da cultivar BRS Itaim os maiores teores de taninos condensados e antocianinas totais. Os grãos crus, cozidos e caldo apresentaram diferença estatisticamente significativa na atividade antioxidante, sendo os melhores resultados nas amostras sem tratamento térmico, com destaque para a BRS Marataoã. Concluiu-se que o cozimento influenciou a concentração dos compostos bioativos e a atividade antioxidante dos grãos, recomendando-se o consumo do feijão-caupi com o caldo de cocção para aproveitamento dos compostos antioxidantes.
\end{abstract}

Palavras-chave: Alimentos funcionais. Antioxidantes. Cocção. Vigna unguiculata (L.) Walp.

\footnotetext{
"Corresponding author

${ }^{1}$ Received for publication in 06/14/2016; accepted in 01/27/2017.

Paper approved from IV CONAC 2016.

Paper extracted from the masters dissertation of the first author, funded by CNPq.

${ }^{2}$ Postgraduate Program in Food and Nutrition, Universidade Federal do Piaú, Teresina, PI, Brazil; rbmc89@hotmail.com.

${ }^{3}$ Planning Management, Fundação Municipal de Saúde, Teresina, PI, Brazil; regmarjoao@hotmail.com.

${ }^{4}$ National Breeding Program for cowpea, Embrapa Meio-Norte, Teresina, PI, Brazil; maurisrael.rocha@embrapa.br.

${ }^{5}$ Department of Nutrition, Universidade Federal do Piaú, Teresina, PI, Brazil; regilda@ufpi.edu.br.
} 


\section{INTRODUCTION}

The cowpea bean, a leguminous plant of the genus Vigna, is widely cultivated in North and Northeast regions of Brazil and in the African continent. It is of interest as a food product owing to its easy climatic adaptability and functional and nutraceutical properties (FROTA et al., 2008; FALADE; KOLAWOLE, 2013; MARQUES et al., 2015). Recently, genetic breeding techniques, in pursuit of desirable characteristics in an ideal cultivar, have been used to produce various materials that make up the cowpea genebanks (FROTA; SOARES; AREAS, 2008).

The cowpea has an excellent nutritive composition: proteins (23 to $25 \%$, mostly globulins and albumins); carbohydrates (56.8\%), B vitamins, minerals (potassium, phosphorus, iron, calcium, manganese, magnesium, and zinc), dietary fiber $(3.9 \%)$, and low fat content $(1.3 \%)$, with a substantial amount of unsaturated fatty acids (45.6 to $78.1 \%$ ). It also contains non-digestible oligosaccharides (raffinose, stachyose, and verbascose) (CARVALHO et al., 2012).

The increasing demand for healthy dietary foods has driven research for foodstuffs that can meet these needs. Vitamin C, $\alpha$-tocopherol, carotenoids, and phenolic compounds that are present in plant products have the ability to reduce oxidative damage associated with many diseases including cancer, cardiovascular disease, atherosclerosis, diabetes, arthritis, among others (SIDDHURAJU; BECKER, 2007).

Polyphenols are chemical structures with hydroxyl groups and aromatic rings (monomers or polymers), showing antioxidant properties. Major polyphenols include flavonoids, phenolic acids, simple phenols, coumarins, tannins, lignins, and tocopherols (ANGELO; JORGE, 2007). These phytochemicals complement the endogenous antioxidants, which regulate the various oxidation-reduction reactions that occur continuously in the body. In turn, phenolic compounds are known to be unstable and are influenced, among other factors, by the temperature used during food processing (SULTANA; ANWAR; IQBAL, 2008).

Thermal processing allows optimal nutrient intake in beans, thus improving their digestion, nutrient absorption, and sensory characteristics. Proper cooking can also reduce non-digestible oligosaccharides and thermolabile anti-nutritional factors, such as trypsin inhibitors and phytates. As a result of the antioxidant properties of these compounds, thermal processing results in substantial changes in the antioxidant capacities of the grains (BENEVIDES et al. 2013; FERNANDES; CALVO; PROENÇA, 2012; KALPANADEVI; MOHAN, 2013).

Thus, the aim of this study was to evaluate the effect of domestic thermal processing (cooking) on the chemical compositions and antioxidant activities in grains of five cultivars of cowpea.

\section{MATERIAL AND METHODS}

\section{Experimental protocol}

Samples of cowpea grains were collected from the experimental field of Embrapa Meio-Norte in Teresina-PI (72 meters altitude, $5^{\circ} 5^{\prime}$ South Latitude and $42^{\circ} 48^{\prime}$ West Longitude) from the first crop of 2013. The grains were kept at the Laboratory of Bromatology and Food Biochemistry (LABROMBIOQ) in the Nutrition Department of the Federal University of Piauí (UFPI) in hermetic packagings at $8{ }^{\circ} \mathrm{C}$ until their analysis.

Five cultivars were analyzed: BRS Marataoã, BR 17-Gurguéia, BRS Itaim, BRS Cauamé, and BRS Guariba. The first two cultivars have colorful seed coats, while the other cultivars have white seed coats.

\section{Sample preparation}

The beans were manually scanned for removal of impurities and unhealthy grains. The grains of each cultivar were subjected to two different preparation procedures. The raw beans were ground using a rotor mill (Tecnal, TE-651/2-T) to a homogeneous powder ( 0.5 mesh). Another batch of beans was cooked without soaking in a 1:5 beans: water ratio $(\mathrm{w} / \mathrm{v})$ in a $2 \mathrm{~L}$ domestic pressure cooker for 780 seconds after constant steam output from the pressure valve. Then, the cooked grains were separated from the cooking broth with the aid of plastic sieves and homogenized in a grau with pistil for further analysis. The homogeneous powders obtained from the raw beans and cooked beans were stored in bags of low density polyethylene and $0.08-\mathrm{mm}$ thick film, and the cooking broths were stored in plastic tubes $(0.05 \mathrm{~L})$, both under refrigeration $\left(8{ }^{\circ} \mathrm{C}\right)$ until analysis. All analyses were performed in triplicate in the period from March 2014 to December 2014.

\section{Proximate composition and total energy value}

Moisture was determined until constant weight was observed after drying in an oven (314D242, Quimis. São Paulo, Brazil) at $105{ }^{\circ} \mathrm{C}$. Ash content was determined after calcination of the samples in a muffle furnace (Q-318M21, Quimis, São Paulo, Brazil) at $550{ }^{\circ} \mathrm{C}$ up to constant mass. Protein concentration was determined using the Macro-Kjeldahl method with a conversion factor of 5.75 (for plant proteins), and lipid content was determined by intermittent hot extraction using hexane as a solvent in a Soxhlet apparatus (ET-044, Tecnal, São Paulo, Brazil) (AOAC, 2005). 
Carbohydrate content was calculated using the difference method, and the total energy value was determined according to Atwater conversion factors (WATT; MERRILL, 1963).

\section{Bioactive compounds}

Several solvents were tested (water, $80 \%$ acetone, and ethanol) because the solubility of phenols varies according to the polarity of the solvent used, the degree of polymerization of phenolic compounds and their interactions with other constituents of food. The best extraction yields were obtained using 50\% methanol-70\% acetone-water extract $(2: 2: 1)$. To obtain the extracts, the procedure was adapted from Rufino et al. (2007).

The levels of the following bioactive compounds were determined using the spectrophotometric method: total phenolic compounds (ROSSI; SINGLETON, 1965), total flavonoids (KIM; JEONG; LEE, 2003 modified by BLASA et al., 2006), anthocyanins (GIUSTI; WROLSTAD, 2001), and condensed tannins (PRICE; SCOYOC; BUTLER, 1978).

\section{Antioxidant activity}

Antioxidant activity was determined using the following methods: 2,2' azino-bis (3-ethylbenzothiazoline-6-sulfonic acid) (ABTS) method described by Re et al. (1999) and 2,2-diphenyl-1-pikrylhydrazil (DPPH) method described by Brand-Williams, Cuvier, and Berset (1995).

\section{Statistical analysis}

Data analysis was performed using the software program 'statistical package for social sciences' (SPSS) version 17.0 (SPSS, 2006). The results were presented as means and standard deviations. Before starting the statistical analysis, the non-parametric Kolmogorov-Smirnov normality test was applied. Normal distribution $(p<0.05)$ was observed between the means of the three replications for each cowpea cultivar. Thereafter, Student's t-test was used to verify the differences between the means of raw and cooked grains (centesimal composition), and one-way ANOVA: post-hoc, Tukey's test was applied at $5 \%$ probability $(\mathrm{p}<0.05)$ with a $95 \%$ confidence level to analyze differences between the means of the cultivars (HILBE, 2013).

\section{RESULTS AND DISCUSSION}

\section{Proximate composition and total energy value}

The grains absorbed water after cooking (see Table 1). This result is in agreement with results of several previous studies (DELFINI; CANNIATTI-BRAZACA, 2008; RAMÍREZ-CÁRDENAS; LEONEL; COSTA, 2008; SILVA; BRIGIDE; CANNIATTI-BRAZACA, 2013). Water absorption capacity is influenced by seed coat characteristics of the grains: thickness, weight, adherence to cotyledons, elasticity, porosity, and colloidal properties. Hence, the analyzed cultivar grains had similar seed coat characteristics because they showed similar grain moisture contents after cooking. The levels of ashes, proteins, lipids, and carbohydrates from the grains of the five cultivars were also not affected by the heat treatment (Table 1).

It is likely that ash content in the cooked grain samples remained unchanged because cooking favors the release of some mineral complexes present in grains, such as the phytic acid-mineral complex, replacing the mineral diffusion losses in the cooking broth (RAMÍREZ-CÁRDENAS; LEONEL; COSTA, 2008).

The presence of the cooking broth associated with grains during the determination of proximate composition may have contributed to the quantification of solubilized proteins, lipids, and carbohydrates, as observed by Silva, Brigide and Canniatti-Brazaca (2013) and Ramírez-Cárdenas, Leonel and Costa (2008).

The cultivar BRS Marataoã showed a significant difference $(p<0.05)$ in the total energy value after cooking, which can be explained by lower levels of lipids and carbohydrates in the grain of this cultivar (Table 1).

\section{Bioactive compounds}

After thermal processing, there was a decrease in the total polyphenol content in the grains of the five cowpea cultivars (Table 2), as observed by Delfini and Canniatti-Brazaca (2008) and Siddhuraju and Becker (2007) in the genotypes of cowpea and common beans.

In the present study, the contents of phenolic compounds were significant, considering the sum of the contents obtained in the cooked grains and respective cooking broths, justified through the reduction of proteins bound to polyphenols on cooking. Therefore, the transfer of compounds to the broth occurs because of the water solubility of these compounds. 
Table 1. Proximate compositions and total energy values of the grains of five cowpea cultivars before and after thermal processing.

\begin{tabular}{|c|c|c|c|}
\hline $\begin{array}{l}\text { Nutrient* } \\
\mathrm{g} / 100 \mathrm{~g}\end{array}$ & Cultivar & $\begin{array}{c}\text { Raw Bean } \\
\text { Mean } \pm \text { SD }\end{array}$ & $\begin{array}{c}\text { Cooked Bean } \\
\text { Mean } \pm \text { SD }\end{array}$ \\
\hline Moisture & $\begin{array}{c}\text { BRS Marataoã } \\
\text { BR } 17 \text { - Gurguéia } \\
\text { BRS Itaim } \\
\text { BRS Cauamé } \\
\text { BRS Guariba }\end{array}$ & $\begin{array}{l}10.7 \pm 1.3^{\mathrm{a} A} \\
10.7 \pm 1.7^{\mathrm{a} A} \\
11.4 \pm 0.9^{\mathrm{a} A} \\
11.0 \pm 0.9^{\mathrm{a} A} \\
11.2 \pm 1.5^{\mathrm{a} A}\end{array}$ & $\begin{array}{l}72.5 \pm 2.0^{\mathrm{a} B} \\
74.8 \pm 3.1^{\mathrm{a} B} \\
75.4 \pm 7.1^{\mathrm{a} B} \\
63.3 \pm 8.7^{\mathrm{a} B} \\
69.0 \pm 4.4^{\mathrm{a}} \mathrm{B}\end{array}$ \\
\hline Ash & $\begin{array}{c}\text { BRS Marataoã } \\
\text { BR } 17 \text { - Gurguéia } \\
\text { BRS Itaim } \\
\text { Cauamé } \\
\text { Guariba }\end{array}$ & $\begin{array}{l}4.5 \pm 0.4^{\mathrm{a}} \mathrm{A} \\
3.8 \pm 0.1^{\mathrm{a}} \mathrm{A} \\
3.7 \pm 0.2^{\mathrm{a}} \mathrm{A} \\
3.7 \pm 0.2^{\mathrm{a}} \mathrm{A} \\
3.7 \pm 0.1^{\mathrm{a}} \mathrm{A}\end{array}$ & $\begin{array}{l}5.3 \pm 0.0^{\mathrm{a} A} \\
4.4 \pm 0.4^{\mathrm{a}} \mathrm{A} \\
3.9 \pm 0.2^{\mathrm{a}} \mathrm{A} \\
3.7 \pm 0.3^{\mathrm{a}} \mathrm{A} \\
4.5 \pm 0.2^{\mathrm{a} A}\end{array}$ \\
\hline Proteins & $\begin{array}{c}\text { BRS Marataoã } \\
\text { BR } 17 \text { - Gurguéia } \\
\text { BRS Itaim } \\
\text { BRS Cauamé } \\
\text { BRS Guariba }\end{array}$ & $\begin{array}{l}16.3 \pm 0.6^{\mathrm{a} A} \\
17.6 \pm 1.9^{\mathrm{a}} \mathrm{A} \\
16.6 \pm 0.9^{\mathrm{a}} \mathrm{A} \\
17.4 \pm 0.7^{\mathrm{a} A} \\
14.5 \pm 0.4^{\mathrm{a} A}\end{array}$ & $\begin{array}{l}16.8 \pm 1.5^{\mathrm{a} A} \\
17.2 \pm 1.3^{\mathrm{a} A} \\
16.6 \pm 0.3^{\mathrm{a} A} \\
17.5 \pm 0.2^{\mathrm{a} A} \\
14.8 \pm 1.4^{\mathrm{a} A}\end{array}$ \\
\hline Lipids & $\begin{array}{c}\text { BRS Marataoã } \\
\text { BR } 17 \text { - Gurguéia } \\
\text { BRS Itaim } \\
\text { Cauamé } \\
\text { Guariba }\end{array}$ & $\begin{array}{l}1.3 \pm 0.2^{\mathrm{a}} \mathrm{A} \\
1.5 \pm 0.4^{\mathrm{a}} \mathrm{A} \\
2.1 \pm 0.3^{\mathrm{a}} \mathrm{A} \\
1.4 \pm 0.3^{\mathrm{a}} \mathrm{A} \\
1.3 \pm 0.3^{\mathrm{a}} \mathrm{A}\end{array}$ & $\begin{array}{l}1 \pm 0.1^{\mathrm{a}} \mathrm{A} \\
1.3 \pm 0.5^{\mathrm{a}} \mathrm{A} \\
2 \pm 0.3^{\mathrm{a}} \mathrm{A} \\
1.9 \pm 0.7^{\mathrm{a}} \mathrm{A} \\
1.6 \pm 0.3^{\mathrm{a}} \mathrm{A}\end{array}$ \\
\hline Carbohydrates & $\begin{array}{c}\text { Marataoã } \\
\text { BR } 17 \text { - Gurguéia } \\
\text { BRS Itaim } \\
\text { BRS Cauamé } \\
\text { BRS Guariba }\end{array}$ & $\begin{array}{l}77.9^{\mathrm{a}} \mathrm{A} \\
77.1^{\mathrm{a}} \mathrm{A} \\
77.6^{\mathrm{a}} \mathrm{A} \\
77.5^{\mathrm{a}} \mathrm{A} \\
80.5^{\mathrm{a}} \mathrm{A}\end{array}$ & $\begin{array}{l}76.9^{\mathrm{a}} \mathrm{A} \\
77.1^{\mathrm{a}} \mathrm{A} \\
77.5^{\mathrm{a}} \mathrm{A} \\
76.8^{\mathrm{a}} \mathrm{A} \\
79.1^{\mathrm{a}} \mathrm{A}\end{array}$ \\
\hline Total energy value (Kcal/g) & $\begin{array}{c}\text { BRS Marataoã } \\
\text { BR } 17 \text { - Gurguéia } \\
\text { BRS Itaim } \\
\text { BRS Cauamé } \\
\text { BRS Guariba }\end{array}$ & $\begin{array}{l}388.6 \pm 0.7^{\mathrm{a}} \mathrm{A} \\
393.9 \pm 2.5^{\mathrm{a}} \mathrm{A} \\
395.7 \pm 1.9^{\mathrm{a}} \mathrm{A} \\
391.9 \pm 1.5^{\mathrm{a} A} \\
391.8 \pm 1.8^{\mathrm{a} A}\end{array}$ & $\begin{array}{l}383.75 \pm 0.7^{\mathrm{a} B} \\
389.27 \pm 0.9^{\mathrm{a}} \mathrm{A} \\
394.04 \pm 2.4^{\mathrm{a}} \mathrm{A} \\
394.70 \pm 2.8^{\mathrm{a}} \mathrm{A} \\
390.10 \pm 2.0^{\mathrm{a}} \mathrm{A}\end{array}$ \\
\hline
\end{tabular}

Means of data from three replications. Same capital letters between raw and cooked beans imply that there is no significant difference, based on the Student's t-test. Same lowercase letters between cultivars in the same column in raw and cooked beans imply that there is no significant difference, based on the Tukey's test. Both tests compare the means at asignificance level of $5 \%$.

*Results expressed on a dry basis.

Total flavonoid contents in the grains and their cooking broths are shown in Table 3. After thermal processing, there was an increase in the total flavonoid contents in the five cultivars, considering cooked beans and cooking broth. Sultana, Anwar and Iqbal (2008) found an increase in the phenolic content in vegetable samples after thermal processing. These authors attributed this increase to the possibly increased solubilization and extraction of these compounds as a result of softening or breakdown of plant cell walls.

According to Machado et al. (2008), losses during processing of these compounds vary, depending on the kinds of food and preparation that are used. Thus, the stability of flavonoids and their glycosylated chemical structures may have contributed to higher extraction of these compounds in samples, in some cases, exceeding the phenolic content, as proteins are possible complexation substrates and may cause underestimation of the levels of total polyphenols.

The concentrations of anthocyanins in the samples are shown in Table 4. Among the analyzed cultivars, raw grains of BRS Itaim showed the highest anthocyanin content $(\mathrm{p}<0.05)$. 
Table 2. Total polyphenols in grains of cowpea cultivars before and after thermal processing and in the cooking broth.

\begin{tabular}{cccc}
\hline & \multicolumn{4}{c}{ Total Polyphenols $\left(\mathrm{mg} \mathrm{GAE}^{-1}\right)$} & \\
\hline Cultivar & Raw Bean & Cooked Bean & Cooking Broth \\
& Mean \pm SD & Mean \pm SD & Mean \pm SD \\
\hline BRS Marataoã & $295.2 \pm 24.8^{\mathrm{a}} \mathrm{A}$ & $131.6 \pm 22.3^{\mathrm{a}} \mathrm{B}$ & $274.3 \pm 21.2^{\mathrm{a}} \mathrm{C}$ \\
BR 17-Gurguéia & $255.7 \pm 10.6^{\mathrm{b}} \mathrm{A}$ & $91.7 \pm 3.3^{\mathrm{b}} \mathrm{B}$ & $163.6 \pm 52.5^{\mathrm{b}} \mathrm{C}$ \\
BRS Itaim & $132.3 \pm 11.4^{\mathrm{c}} \mathrm{A}$ & $66.5 \pm 7.0^{\mathrm{c}} \mathrm{B}$ & $95.2 \pm 21.8^{\mathrm{c}} \mathrm{C}$ \\
BRS Cauamé & $98.1 \pm 9.0^{\mathrm{d}} \mathrm{A}$ & $55.0 \pm 10.0^{\mathrm{d}} \mathrm{B}$ & $72.8 \pm 7.1^{\mathrm{d}} \mathrm{C}$ \\
BRS Guariba & $89.4 \pm 11.1^{\mathrm{e}} \mathrm{A}$ & $49.0 \pm 8.0^{\circ} \mathrm{B}$ & $62.9 \pm 12.2^{\mathrm{e}} \mathrm{C}$ \\
\hline
\end{tabular}

Means of data from three replications. Same lowercase letters between cultivars in the same column indicate that there is no significant difference, based on Tukey's test. Same capital letters between raw bean, cooked bean, and cooking broth indicate that there is no significant difference, based on Tukey's test. The means were compared at a significance level of $5 \%$.

Results expressed on wet basis.

Table 3. Total flavonoids in grains of cowpea cultivars before and after thermal processing and in the cooking broth.

\begin{tabular}{lccc}
\hline & \multicolumn{2}{c}{ Total Flavonoids $\left(\mathrm{mg} \mathrm{EQ}^{-1}\right)$} & \\
\hline Cultivar & Raw Bean & Cooked Bean & Cooking Broth \\
& Mean \pm SD & Mean \pm SD & SD \\
\hline BRS Marataoã & $164.0 \pm 14.1^{\mathrm{a}} \mathrm{A}$ & $207.7 \pm 28.9^{\mathrm{a}} \mathrm{B}$ & $350.4 \pm 49.1^{\mathrm{a}} \mathrm{C}$ \\
BR 17-Gurguéia & $158.7 \pm 25.3^{\mathrm{a}} \mathrm{A}$ & $137.2 \pm 32.9^{\mathrm{b}} \mathrm{B}$ & $189.0 \pm 3.0^{\mathrm{b}} \mathrm{C}$ \\
BRS Itaim & $126.9 \pm 13.7^{\mathrm{b}} \mathrm{A}$ & $86.8 \pm 25.1^{\mathrm{c}} \mathrm{B}$ & $121.9 \pm 38.6^{\mathrm{c}} \mathrm{A}$ \\
BRS Cauamé & $124.4 \pm 5.6^{\mathrm{b}} \mathrm{A}$ & $62.9 \pm 11.1^{\mathrm{d}} \mathrm{B}$ & $75.6 \pm 4.5^{\mathrm{d}} \mathrm{B}$ \\
BRS Guariba & $109.0 \pm 15.8^{\mathrm{c}} \mathrm{A}$ & $69.3 \pm 20.0^{\mathrm{d}} \mathrm{B}$ & $59.8 \pm 8.4^{\mathrm{e}} \mathrm{C}$ \\
\hline
\end{tabular}

Means of data from three replications. Same lowercase letters between cultivars in the same column indicate that there is no significant difference, based on Tukey's test. Same capital letters between raw bean, cooked bean, and cooking broth indicate that there is no significant difference, based on Tukey's test. The means were compared at a significance level of 5\%. Results expressed on wet basis.

Table 4. Total anthocyanins in grains of cowpea cultivars before and after thermal processing and in the cooking broth.

\begin{tabular}{cccc}
\hline & \multicolumn{2}{c}{ Anthocyanins $\left(\mathrm{mg} \mathrm{cy}-3-\mathrm{glu}^{-1}\right)$} & \\
\hline Cultivar & Raw Bean & Baked Bean & Cooking Broth \\
& Mean $\pm \mathrm{SD}$ & Mean $\pm \mathrm{SD}$ & Mean \pm SD \\
\hline BRS Marataoã & $0.2 \pm 0.0^{\mathrm{a}} \mathrm{A}$ & $\mathrm{ND}^{*}$ & $0.1 \pm 0.0^{\mathrm{a}} \mathrm{C}$ \\
BR17-Gurguéia & $0.6 \pm 0.0^{\mathrm{b}} \mathrm{A}$ & $0.1 \pm 0.0^{\mathrm{a}} \mathrm{B}$ & $0.1 \pm 0.0^{\mathrm{a}} \mathrm{B}$ \\
BRS Itaim & $1.8 \pm 0.0^{\mathrm{c}} \mathrm{A}$ & $0.1 \pm 0.0^{\mathrm{a}} \mathrm{B}$ & $0.1 \pm 0.0^{\mathrm{a}} \mathrm{B}$ \\
BRS Cauamé & $0.3 \pm 0.0^{\text {ad }}$ & $\mathrm{ND}$ & $\mathrm{ND}$ \\
BRS Guariba & $0.1 \pm 0.0^{\mathrm{e}} \mathrm{A}$ & $\mathrm{ND}$ & $\mathrm{ND}$ \\
\hline
\end{tabular}

Means of data from three replications. Same lowercase letters between cultivars in the same column indicate that there is no significant difference, based on Tukey's test. Same capital letters between raw bean, cooked bean, and cooking broth indicate that there is no significant difference, based on Tukey's test. The means were compared at a significance level of $5 \%$.

Results expressed on wet basis.

*ND (not detected).

The emphasis on the content of anthocyanins in the grains of BRS Itaim can be justified by the fact that genetic variability may contribute to a change in the profile of phenolic compounds of each grain.

Andrade and Ogliari (2010), in a study on anthocyanin content in cowpea, determined a content of $2.20 \mathrm{mg}^{-1}$ in grains of the cultivar BRS Marataoã, a value greater than the one determined in the present study. However, anthocyanin contents in grains of both BRS Novaera and BRS Tumucumaque cultivars were $1.02 \mathrm{mg}^{-1}$.
Ha, Noh and Lee (2010) identified five types of anthocyanins in cowpea: delphinidin 3-glucoside, cyanidin 3-glucoside, petunidin 3-glucoside, 3-glucoside peonidin, and malvidin-3-glucoside.

Thermal processing caused a decrease in the total anthocyanin contents in the grains of the five cowpea cultivars. Thus, the sum of the levels of these phytochemicals in the cooked grains and cooking broth did not exceed the levels found in the raw grains. This factor can be explained by the effect of temperature on the stability of anthocyanins, 
wherein degradation is greater at higher temperatures.

As shown in Table 5, thermal processing may cause attenuation of the contents of condensed tannin in BRS Itaim and BRS Cauamé cultivars, owing to the ability of tannins to diffuse from the cotyledon into the endosperm and bind to proteins. This decrease was also observed by Benevides et al. (2013) and Ramírez-Cárdenas, Leonel and Costa (2008) while evaluating different beans with $64-83 \%$ reduction.

Table 5. Condensed tannins in grains of cowpea cultivars before and after thermal processing and in the cooking broth.

\begin{tabular}{cccc}
\hline \multicolumn{4}{c}{ Condensed Tannins $\left(\mathrm{mg} \mathrm{EC}^{-1}\right)$} \\
\hline Cultivar & $\begin{array}{c}\text { Raw Bean } \\
\text { Mean } \pm \mathrm{SD}\end{array}$ & $\begin{array}{c}\text { Cooked Bean } \\
\text { Mean } \pm \text { SD }\end{array}$ & $\begin{array}{c}\text { Cooking Broth } \\
\text { Mean } \pm \text { SD }\end{array}$ \\
\hline BRS Marataoã & $2.9 \pm 0.8^{\mathrm{a}} \mathrm{A}$ & $2.0 \pm 0.3^{\mathrm{a}} \mathrm{B}$ & $1.5 \pm 0.1^{\mathrm{a}} \mathrm{C}$ \\
BR 17-Gurguéia & $1.9 \pm 0.7^{\mathrm{a}} \mathrm{A}$ & $1.8 \pm 0.4^{\mathrm{a}} \mathrm{A}$ & $0.4 \pm 0.0^{\mathrm{a}} \mathrm{B}$ \\
BRS Itaim & $4.9 \pm 1.0^{\mathrm{b}} \mathrm{A}$ & $2.6 \pm 0.2^{\mathrm{a}} \mathrm{B}$ & $\mathrm{ND}^{*}$ \\
BRS Cauamé & $2.1 \pm 0.1^{\mathrm{a}} \mathrm{A}$ & $1.5 \pm 1.0^{\mathrm{a}} \mathrm{B}$ & $\mathrm{ND}$ \\
BRS Guariba & $1.9 \pm 0.1^{\mathrm{a}} \mathrm{A}$ & $1.8 \pm 0.2^{\mathrm{a}} \mathrm{A}$ & $0.3 \pm 0.0^{\mathrm{a}} \mathrm{B}$ \\
\hline
\end{tabular}

Means of data from three replications. Same lowercase letters between cultivars in the same column indicate that there is no significant difference, based on Tukey's test. Same capital letters between raw bean, cooked bean, and cooking broth indicate that there is no significant difference, based on Tukey's test. The means were compared at a significance level of $5 \%$.

Results expressed on wet basis.

*ND (not detected).

In turn, the contents of condensed tannins of cultivars BRS Marataoã, BR 17-Gurguéia and BRS Guariba, increased after thermal processing, possibly considering the compounds that migrated to the cooking broth. In the study by Avanza et al. (2013), the cowpea grain variety "Colorado" showed the same levels of tannins after three cooking times (20, 40, and 60 minutes).

According to Barampama and Simard (1995) and Oliveira et al. (2001), although the broth is a possible source for these compounds, insoluble molecular complexes may be formed between tannins and related compounds that are present in the broth during cooking (proteins, lipids, and oligosaccharides), which cannot be extracted and quantified by analytical techniques, resulting in underestimation of their values.

\section{Antioxidant activity}

As shown in Table 6, thermal processing also affected the antioxidant activity of cowpea grains of the cultivars. BRS Marataoã cultivar showed the highest antioxidant activity in both methods, both before and after processing and in the cooking broth, followed by BR 17-Gurguéia.

Table 6. Antioxidant activity of grains of cowpea cultivars before and after thermal processing and in the cooking broth.

\begin{tabular}{|c|c|c|c|c|}
\hline \multicolumn{5}{|c|}{ Antioxidant Activity $\left(\mu \mathrm{mol}\right.$ TEAC $\left.^{-1}\right)$} \\
\hline Method & Cultivar & $\begin{array}{c}\text { Raw Bean } \\
\text { Mean } \pm \text { SD }\end{array}$ & $\begin{array}{c}\text { Cooked Bean } \\
\text { Mean } \pm \text { SD }\end{array}$ & $\begin{array}{c}\text { Cooking Broth } \\
\text { Mean } \pm \text { SD }\end{array}$ \\
\hline \multirow{5}{*}{ DPPH } & BRS Marataoã & $2586.3 \pm 72.7^{\mathrm{a}} \mathrm{A}$ & $917.4 \pm 64.9^{\mathrm{a}} \mathrm{B}$ & $2479.1 \pm 83.8^{\mathrm{a} C} \mathrm{C}$ \\
\hline & BR 17-Gurguéia & $2008.1 \pm 63.4^{\mathrm{b}} \mathrm{A}$ & $559.6 \pm 59.7^{\mathrm{b}} \mathrm{B}$ & $1181.8 \pm 92.5^{\mathrm{b}} \mathrm{C}$ \\
\hline & BRS Itaim & $736.2 \pm 28.5^{\mathrm{c}} \mathrm{A}$ & $227.1 \pm 22.8^{\mathrm{c}} \mathrm{B}$ & $495.3 \pm 40.1^{\mathrm{c}} \mathrm{C}$ \\
\hline & BRS Cauamé & $465.6 \pm 16.5^{\mathrm{d}} A$ & $169.7 \pm 54.0^{\mathrm{d}} \mathrm{B}$ & $279.4 \pm 83.4^{\mathrm{d}} \mathrm{C}$ \\
\hline & BRS Guariba & $362.9 \pm 17.4^{\mathrm{e}} \mathrm{A}$ & $130.7 \pm 41.9^{\mathrm{e}} \mathrm{B}$ & $179.2 \pm 65.3^{\mathrm{e}} \mathrm{C}$ \\
\hline \multirow{5}{*}{ ABTS } & BRS Marataoã & $2982.1 \pm 22.6^{\mathrm{a}} \mathrm{A}$ & $896.0 \pm 20.0^{\mathrm{a}} \mathrm{B}$ & $2850.3 \pm 58.8^{\mathrm{a}} \mathrm{C}$ \\
\hline & BR17-Gurguéia & $2025.4 \pm 22.0^{\mathrm{b}} \mathrm{A}$ & $691.3 \pm 48.1^{\mathrm{b}} \mathrm{B}$ & $1040.3 \pm 10.0^{b} \mathrm{C}$ \\
\hline & BRS Itaim & $723.6 \pm 11.1^{\mathrm{c}} \mathrm{A}$ & $430.4 \pm 77.9^{\mathrm{c}} \mathrm{B}$ & $523.9 \pm 41.3^{\mathrm{c}} \mathrm{C}$ \\
\hline & BRS Cauamé & $581.3 \pm 64.4^{\mathrm{d}} \mathrm{A}$ & $303.2 \pm 97.7^{\mathrm{d}} B$ & $423.2 \pm 56.5^{\mathrm{d}} \mathrm{C}$ \\
\hline & BRS Guariba & $515.7 \pm 21.5^{\mathrm{e}} \mathrm{A}$ & $326.5 \pm 94.3^{\mathrm{e}} \mathrm{B}$ & $387.1 \pm 73.7^{\mathrm{e}} \mathrm{C}$ \\
\hline
\end{tabular}

Means of data from three replications. Same lowercase letters between cultivars in the same column indicate that there is no significant difference, based on Tukey's test. Same capital letters between raw bean, cooked bean, and cooking broth indicate that there is no significant difference, based on Tukey's test. The means were compared at a significance level of $5 \%$.

Results expressed on wet basis. 
Both these cultivars have dark seed coats, similar to the observation of the study by Silva, Rocha and Canniatti-Brazaca (2009), where the grains of colored varieties showed higher levels of phenolic compounds, resulting in higher antioxidant activities of the grains. The antioxidant activity evaluated by the two methods is attributed to the presence of phenolic compounds. Among these compounds, total flavonoids are possibly the main components that are responsible for this activity, since they are in greater quantities in the grains and cooking broths.

Cooking promoted a decrease in the antioxidant activities of grains, as observed by Siddhuraju and Becker (2007), who analyzed the effect of thermal processing on two cowpea genotypes, in which the raw grains had EC50 (concentration of the sample required to inhibit 50\% of the DPPH radical) contents of 618 and $705 \mathrm{mg}^{-1}$ of DPPH, compared with 1238 and $1922 \mathrm{mg}^{-1}$ of DPPH after processing.

However, despite the reduction in antioxidant activity in the cooked grains, there was an increase in the antioxidant activities on considering broth and cooked grains together.

\section{CONCLUSION}

The ash, proteins, lipids, and carbohydrates contents in the five cowpea cultivar grains were not affected by heat treatment. After cooking, cowpea cultivars showed high contents of bioactive compounds, considering both the grains and cooking broth. The polyphenols and total flavonoids contents were highest in the BRS Marataoã and BR 17-Gurguéia cultivars, and they also showed the highest antioxidant activities. BRS Itaim cultivar showed high contents of anthocyanins and condensed tannins. The antioxidant activities of the cowpea cultivars were higher in raw beans and cooking broth and lower in cooked grains in both methods. Therefore, it is recommended that cowpea should be consumed through preparations that use cooked beans with the cooking broth.

\section{ACKNOWLEDGMENTS}

The authors thank the CNPq via Universal Notice - process number 482292 / 2011-3, the CAPES-CNPq via Casadinho-PROCAD Notice - process number 552239/2011-8, the Embrapa Meio-Norte via 01/2012 Macroprograma Notice, for the financial support provided, and CAPES for the master's scholarship.

\section{REFERENCES}

ANDRADE, D. F.; OGLIARI, P. J. Estatística para as ciências agrárias e biológicas: com noções de experimentação. 2. ed. Florianópolis, SC: UFSC, 2010. 470 p.

ANGELO, P. M.; JORGE, N. Compostos fenólicos em alimentos - uma breve revisão. Revista Instituto Adolfo Lutz, São Paulo, v. 66, n. 1, p. 232-240, 2007.

ASSOCIATION OF OFFICIAL ANALYTICAL CHEMISTS - AOAC. Official Methods of Analysis of the Association of Analytical Chemists. 15. ed. Washington DC: AOAC Press, 2005.

AVANZA, M. et al. Nutritional and anti-nutritional components of four cowpea varieties under thermal treatments: principal component analysis. LWT - Food Science and Technology, London, v. 51, n. 1, p. 148-157, 2013.

BARAMPAMA, Z.; SIMARD, R. E. Effects of soaking, cooking and fermentation on composition, in-vitro starch digestibility and nutritive value of common beans. Plant Foods for Human Nutrition, Berlim, v. 48, n. 4, p. 349-365, 1995.

BENEVIDES, C. M. J. et al. Efeito do processamento sobre os teores de oxalato e tanino em maxixe (Cucumisanguria L.), jiló (Solanumgilo), feijão verde (Vigna unguiculata (L.) Walp) e feijão andu (Cajanuscajan (L.) Mill sp). Alimentos e Nutrição, Araraquara, v. 24, n. 3, p. 321-327, 2013.

BLASA, M. et al. Raw Millefiori honey is packed full of antioxidants. Food Chemistry, United Kingdom, v. 97, n. 2, p. 217-222, 2006.

BRAND-WILLIAMS, W.; CUVIER, M. E.; BERSET, C. Use of a free radical method to evaluate antioxidant activity. LWT - Food Science and Technology, London, v. 28, n. 1, p. 25-30, 1995.

CARVALHO, A. F. U. et al. Nutritional ranking of 30 Brazilian genotypes of cowpeas including determination of antioxidant capacity and vitamins. Journal of Food Composition and Analysis, v. 26, n. 1-2, p. 81-88, 2012.

DELFINI, R. A.; CANNIATTI-BRAZACA, S. G. Polyphenols and their interaction with digestibility and cooking time in common beans (Phaseolus vulgaris L.). Alimentos e Nutrição, Araraquara, v. 19, n. 4, p. 401-407, 2008. 
FALADE, K. O.; KOLAWOLE, T. A. Effect of irradiation dose on physical, functional and pasting properties of cowpea (Vigna unguiculata L. Walp) cultivars. Journal of Food Process Engineering, Westport, v. 36, n. 2, p.147-59, 2013.

FERNANDES, A. C.; CALVO, M. C. M.; PROENÇA, R. P. C. Técnicas de pré-preparo de feijões em unidades produtoras de refeições das regiões Sul e Sudeste do Brasil. Revista de Nutrição, Campinas, v. 25, n. 2, p. 259-269, 2012.

FROTA, K. M. G. et al. Cholesterol-lowering properties of whole cowpea seed and its protein isolate in hamsters. Journal of Food Science, Chicago, v. 73, n. 9, p. 235-240, 2008.

FROTA, K. M. G.; SOARES, R. A. M.; ARÊAS, J. A. G. Composição química do feijão-caupi (Vigna unguiculata (L.) Walp), cultivar BRS-Milênio. Ciência e Tecnologia de Alimentos, Campinas, v. 28, n. 2, p. 470-476, 2008.

GIUSTI, M. M.; WROLSTAD, R. E. Anthocyanins. characterization and measurement with UV-Visible Spectroscopy. In: WROLSTAD, R. E. (Ed.). Current Protocols in Food Analytical Chemistry. New York: John Wiley \& Sons, v. 1, n. 2, p. 1-13, 2001.

HA, D.; NOH, M.; LEE,Y. Bias reduction of likeli-hood estimators in semi-parametric frailty models. Scandinavian Journal of Statistics, New York, v. 37, n. 2, p. 307-320, 2010.

HILBE, J. Methods of Statistical Model Estimation. Boca Raton, FL: Chapman \& Hall/CRC Press, 2013. 255 p.

KALPANADEVI, V.; MOHAN, V. R. Effect of processing on antinutrients and in vitro protein digestibility of the underutilized legume, Vigna unguiculata L. Walp subsp. Unguiculata. LWT - Food Science and Technology, New York, v. 51, n. 2, p. 455-461, 2013.

KIM, D.; JEONG, S. W.; LEE, C. Y. Antioxidant capacity of phenolic phytochemicals from various cultivars of plums. Food Chemistry, United Kingdom, v. 81, n. 3, p. 321-326, 2003.

MACHADO, H. et al. Flavonóides e seu potencial terapêutico. Boletim do Centro de Biologia da Reprodução, Juiz de Fora, v. 27, n. 1-2, p. 33-39, 2008.

MARQUES, M. R. et al. Effect of cooking on the thermal behavior of the cowpea bean oil (Vigna unguiculata L. Walp). Journal of Thermal Analysis and Calorimetry, Budapeste, v. 120, n. 1, p. 289-296, 2015.

OLIVEIRA, A. C. et al. The elimination of the not absorved water during common bean soaking resulted in weight gain in rats. Revista de Nutrição, Campinas, v. 14, n. 2, p. 153-155, 2001.

PRICE, M. L.; SCOYOC, S. V.; BUTLER, L. G. A critical evaluation of the vanillin reaction as an assay for tannin in sorghum grain. Journal of Agriculture and Food Chemistry, Washington, v. 26, n. 5, p. 1214-1218, 1978.

RAMÍREZ-CÁRDENAS, L.; LEONEL, A. J.; COSTA, N. M. B. Efeito do processamento doméstico sobre o teor de nutrientes e de fatores antinutricionais de diferentes cultivares de feijão comum. Ciência e Tecnologia de Alimentos, Campinas, v. 28, n. 1, p. 200-213, 2008.

RE, R. et al. Antioxidant activity applying an improved ABTS radical cátion decolorization assay. Free Radical Biology and Medicine, New York, v. 26, n. 9-10, p. 1231-1237, 1999.

ROSSI, J. A.; SINGLETON, V. L. Colorimetry of total phenolics with phosphomolybdic-phosphotungstic acid reagents. American Journal of Enology and Viticulture, Davis, v. 20, n. 2, p. 144-158, 1965.

RUFINO, M. S. M. et al. Metodologia científica: determinação da atividade antioxidante total em frutas pela captura do radical livre DPPH. Teresina: Embrapa Agroindústria Tropical, 2007. 4 p. (Comunicado Técnico, 127).

SIDDHURAJU, P.; BECKER, K. The antioxidant and free radical scavenging activities of processed cowpea (Vigna unguiculata (L.) Walp.) seed extracts. Food Chemistry, United Kingdom, v. 101, n. 1, p. 10-19, 2007.

SILVA, A. G.; ROCHA, L. C.; CANNIATTI-BRAZACA, S. G. Caracterização físico-química, digestibilidade protéica e atividade antioxidante de feijão comum (Phaseolusvulgaris L.). Alimentos e Nutrição, Araraquara, v. 20, n. 4, p. 591-598, 2009.

SILVA, M. O.; $\quad$ BRIGIDE, P.; CANNIATTI-BRAZACA, S. G. Caracterização da composição centesimal e mineral de diferentes cultivares de feijão comum crus e cozidos. Alimentos e Nutrição, Araraquara, v. 24, n. 3, p. 339-346, 2013.

SPSS, Statistical Package for the Social Sciences SPPS, versão 17.0, 2006. 
SULTANA, B.; ANWAR, F.; IQBAL, S. Effect of different cooking methods on the antioxidant activity of some vegetables from Pakistan. International Journal of Food Science and Technology, Oxford, v. 43, n. 3, p. 560-567, 2008.

WATT, B.; MERRILL, A. L. Composition of foods: raw, processed, prepared. Washington DC: Consumer and Food Economics Research. Divison/ Agricultural Service (Agriculture Handbook, 8), 1963. $198 \mathrm{p}$. 